\title{
Infiltration Rates on Rootplowed Rangeland
}

\author{
JOHN M. TROMBLE
}

\begin{abstract}
Infiltration and runoff from mechanically treated arid Southwestern rangeland were measured. Control plots dominated by creosotebush had greater infiltration rates than the 1972 and 1976 rootplowed and seeded treatments, stressing the importance of cover for reducing runoff and controlling erosion. Infiltration rates on dry soils were significantly higher on the 1972 rootplowed and seeded treatment compared with the 1976 rootplowed and seeded treatment, indicating the lack of soil structure in the 1976 treatment.
\end{abstract}

In the arid and semiarid rangelands in the southwestern United States, rainfall is insufficient and its distribution too uncertain for maintaining vegetation to protect the soil adequately. Attempts have been made to convert sparse desert vegetation, which is often not suited for grazing, to more desirable plant species (Tromble 1976). To establish new species and manage these arid rangelands for maximum productivity, it is important to know which factors control water yield. Rowe and Reimann (1961) listed soil depth and water storage capacity, rainfall amount and distribution, and the type of vegetation, before and after site conversion, as important factors affecting soil water yield. Other factors, such as storm intensity, watershed size, and soil surface characteristics, also affect water yield.

Arid and semiarid shrub-covered watersheds can sometimes be converted to grass, increasing onsite forage productivity. Rootplowing to kill the brush and then seeding usable forage species is an important method used in the southwestern United States to improve rangeland. This method disturbs the soil surface, which can enhance water storage, and at the same time prepares a seedbed.

Sparsity of vegetation on arid and semiarid rangelands means that soil surface conditions are of prime importance in determining infiltration rates (Duley and Kelley 1939; Horton 1940; Dixon 1966; and Kincaid and Williams 1966). Simple correlations between infiltration rates during the second 30-minute period of 1-hour infiltration tests showed that the soil structure of the uppermost horizon was highly correlated with water intake. Texture of the horizon just below was second in importance, and the nature of the lower

\footnotetext{
Author is hydrologist, Science and Education Administration, Agricultural Research, U.S. Department of Agriculture, Jornada Experimental Range, P.O. Box 698, Las Cruces, New Mexico 88001.

Manuscript received August 10, 1979.
}

boundary of the upper horizon was third (Rauzi and Fly 1968).

Kincaid et al. (1964) reported a strong relationship between infiltration and plot cover, with most plot cover variation associated with differences in crown spread of shrubs and half-shrubs. Rauzi and Fly (1968) determined that the amount of vegetation, both old and new, had the greatest general correlation with water intake rate on midcontinental rangelands. This correlation between vegetative cover and infiltration on midcontinental rangelands, as compared with arid rangelands, may indicate a possible threshold value where vegetative cover influences infiltration more than soil structure.

In Arizona, Kincaid and William (1966) cleared brush and pitted and seeded plots to grass for runoff studies; they found little correlation between these treatments and surface runoff. However, as the amounts of crown cover increased runoff significantly decreased. Schreiber and Kincaid (1967) reported that average runoff for any location year increased as precipittion volume increased, decreased as vegetation crown cover increased, and increased as antecedent soil moisture increased.

Dortignac and Hickey (1963) reported on about 30,000 acres (12,915 ha) on the Rio Puerco drainage in New Mexico treated by ripping and seeding to grass and browse species. Surface runoff was reduced 97 and $85 \%$ the first and third years after treatment, respectively. Erosion was reduced by 86 and $30 \%$ for the first and third years after the ripping operation, respectively.

Branson et al. (1966) reported on seven different mechanical treatments. The most effective two were contour furrowing at 3-and 5-foot (.92 and $1.53 \mathrm{~m}$ ) intervals and broadbase furrowing with low dikes about 1.5 feet $(0.46 \mathrm{~m})$ high.

Contour furrows in southern Arizona lasted about 15 years, Brown and Everson (1952). Grass production was 2.5 times greater on the treated than on the adjacent untreated areas 10 years after treatment. Treatment effects on runoff were not determined in that study.

Hydrologic information concerning the effects of rangeland conversion treatments on surface runoff is lacking. The purpose of this study was to evaluate the effects of the rootplowing and seeding treatment on infiltration and runoff. 


\section{Study Area}

The research site used for my study is within the Jornada Experimental Range, a 193,000-acre (78,455-ha) experimental ranch where the Science and Education Administration is conducting hydrologic and range research. Two sites were selected for infiltrometer tests to quantify differences in infiltration and runoff rates encountered on different age rootplow treatments of sites dominated by creosotebush (Larrea tridentata). One area was rootplowed in 1972 and the other in 1976. Grasses seeded were blue panicgrass (Panicum antidotale), lehmann lovegrass (Eragrostis lehmanniana), Boer lovegrass (Eragrostis chloromelas), Texas bluestem (Andropogon ischaemum), and black gramagrass (Bouteloua eriopoda). On a nearby site, infiltration tests were made so that comparisons could be made of both creosotebush cover and bare soil along with the two seeding treatments.

The soils on the study area are of the Tencee series (Typic Paleorthids). These are shallow soils that range from poorly drained to well drained. They are moderately permeable-water penetrates to 20 inches $(51 \mathrm{~cm})$ (Soil Conservation Service 1972)and are in the hydrologic group $D$ having a final infiltration rate (f) of 0.0 to $0.5 \mathrm{inches} / \mathrm{hr}(0.0-0.13 \mathrm{~cm} / \mathrm{hr})$ (Musgrave 1955).

Annual precipitation on the Jornada Experimental Range is about 10 inches $(25.4 \mathrm{~cm})$. About $40 \%$ comes from winter frontal storms and $60 \%$ from short duration, high intensity convective summer storms.

The infiltrometer plots were 39.4 inches ( $1 \mathrm{~m}$ on each side, with four replications per treatment. Data were grouped to determine possible infiltration differences using an analysis of variance. The treatments were defined as follows:

$\begin{array}{ll}\text { Treatment } & \text { Identification } \\ \text { Control, creosotebush } & \text { CC } \\ \text { Control, bare soil } & \text { CB } \\ \text { Rootplow, 1972 } & \text { RP2 } \\ \text { Rootplow, 1976 } & \text { RP6 }\end{array}$

A sprinkling type rainfall simulator was used to examine infiltration runoff relations for the treatments. Plot runoff was recorded continuously by a water stage recorder installed on a volumetric tank. Infiltration rates were calculated as the difference between application and runoff rate. Antecedent soil moisture (defined as wet) effects were determined on the plots by repeating the infiltration test $24 \mathrm{hr}$ after the initial test.

Simulated rainfall was measured on a test plot with cans placed on a 7.9-inch $(20 \mathrm{~cm})$ grid and was found to be uniform over the plot. The 7 -inch $/ \mathrm{hr}(17.8 \mathrm{~cm} / \mathrm{hr})$ design application rate was verified by placing a plastic sheet over the plot and measuring outflow.

\section{Results and Discussion}

Figures 1 and 2 summarize the infiltration data for dry (initial infiltrometer run) and wet soil, respectively, for the four different sites.

The data were subjected to an analysis of variance to test for significance for time to beginning of runoff $\left(t_{0}\right.$ to $\left.t_{r}\right)$ and for infiltration. There was no significant difference between treatments in the time from start of simulated rainfall to start of runoff. Average time for $t_{0}$ to $t_{r}$ was 3 min for all treatments. Differences in infiltration were examined after $10,20,30$, and $60 \mathrm{~min}$. An $F$-test indicated no significant differences $(P=.95)$ in infiltration rates among treatments after 10 minutes. Differences in infiltration rates among treatments were highly significant after 20,30 , and $60 \mathrm{~min}$.

A Duncan's multiple range test was used to test for significant differences in infiltration among treatment means after 60 minutes. The Duncan's test (Table 1) showed that the $\mathrm{CC}$ dry treatment had a significantly greater infiltration than any of the other treatments. There was no significant

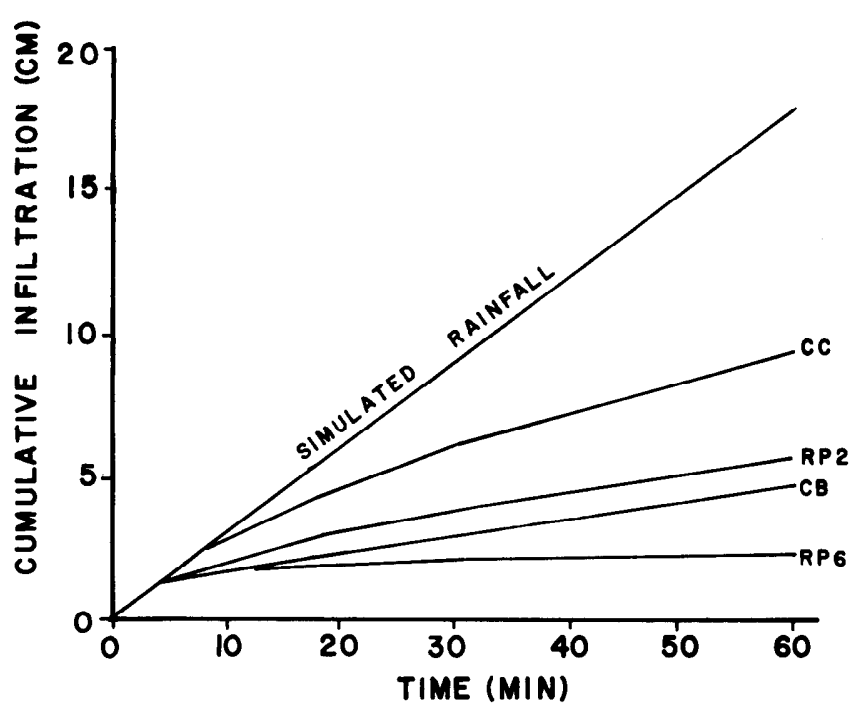

Fig. 1. Infiltration versus time curves for the creosotebush control (CC) rootplow 1972 (RP2), rootplow 1976 (RP6), and the control bare soil (CB) plots for the dry soil. Each curve is the average of four replications.

difference between means for the CB wet, RP2 wet, and RP6 dry, and RP6 wet treatments. Treatments CB when dry, RP2 when dry and CC when wet were not significantly different from each other, but they had significantly greater infiltration than CB treatments when wet, RP2 when wet, and RP6 when dry.

The greater infiltration rates on the 1972 rootplow treatment when dry may have resulted because of soil pore formation being better developed in the soil as compared with the 1976 rootplow treatment. Also, the RP2 treatment had a much greater vegetation cover $(800 \mathrm{lb} / \mathrm{acre}, 363$ $\mathrm{kg} / \mathrm{ha}$ ) of air dry forage compared to the recently seeded RP6 treatment.

The antecedent soil moisture determinations indicated infiltration was lower when soils were moist (Fig. 2) than when dry (Fig. 1) except on treatment RP6. The percentage change in infiltration rates (Table 2 ) as influenced by antecedent soil moisture was greatest on the CB plots and least for the CC plots. The percentage change for the RP2 plots was

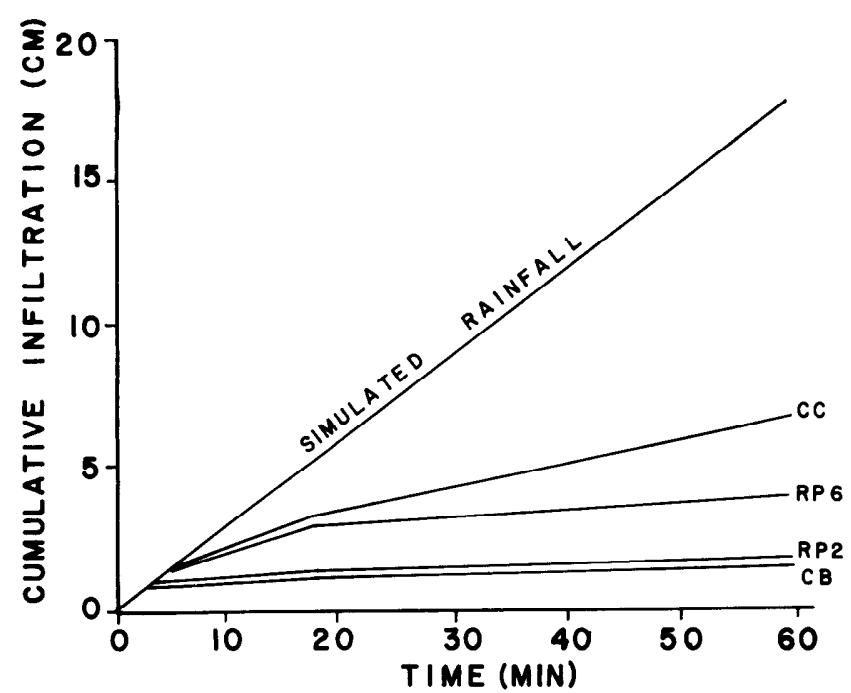

Fig. 2. Infiltration versus time curves for the creosotebush control (CC), rootplow 1972 (RP2), rootplow 1976 (RP6), and the control bare soil (CB) plots for the wet soil. Each curve is the average of four replications. 
Table 1. Differences between treatment means for infiltration rates after 60 minutes.

\begin{tabular}{lllllllll}
\hline \hline \multicolumn{10}{c}{ Treat- } \\
ment** & & & & & & \\
CB & RP2 & RP6 & RP6 & CB & RP2 & CC & CC \\
wet & wet & dry & wet & dry & dry & wet & dry \\
\hline
\end{tabular}

means

(cm/hr)

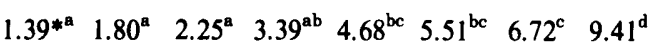

Values followed by the same letter indicate no significant difference at the .95 level treatment means according to Duncan's multiple range test.

**CB = control, bare soil R P2-rootplow, 1972; RP6-rootplow, 1976; CC = control, cresotebush.

slightly less than for the CB plots. On the R P6 plots, where more water infiltrated under the wet treatment than under the dry treatment, the difference was not statistically significant. Possibly the dry, fine soil deposited on the surface by the recent rootplow treatment formed a barrier limiting water infiltration into the dry soil as compared with that on the wet soil. The infiltrometer runs were made within 2 months of the 1976 rootplow treatment. Thus, there was not enough time for the establishment of a pore structure in the soil. Precipitation events which might have enhanced pore formation were minimal during those 2 months.

The results from these infiltrometer determinations illustrate the infiltration increases that result from vegetation cover. In this case, the creosotebush cover provided more protection to the soil than did the vegetation on either the 1972 rootplow or the 1976 rootplow plots. Gardner ${ }^{1}$ (unpublished data) found that infiltration rates were higher on protected areas where vegetation cover was greater.

Comparison of the creosotebush control (wet) with the bare soil control (wet) (Table 1) indicated a 4.8-fold increase in infiltration after $60 \mathrm{~min}$ from the creosotebush control plots. Thus, bare soil allows increased surface runoff and erosion potential. Infiltration after $60 \mathrm{~min}$ on a moist soil was 3.7 and 2.0 times greater for the creosotebush control plots than for the plots rootplowed in 1972 and 1976, respectively. Even though the rootplow treatment roughened the soil surface as compared with the control, this roughness was apparently not adequate to offset the protection afforded by the vegetation cover on the creosotebush plots.

\section{Summary and Conclusions}

Infiltration was greater on untreated plots dominated by cresotebush than on the treated plots. Apparently, this was a result of more vegetation cover on creosotebush plots when compared to the other treatments.

Infiltration on moistened soils was generally less than on dry soils. The percentage change in infiltration rates was least for the creosotebush control plots and greatest for the bare soil plots.

When both were dry, infiltration was greater on the plots rootplowed in 1972 than on those rootplowed in 1976.

Infiltration increased 4.8 -fold after 60 min on moist soils on the creosotebush control plots as compared with the bare plots. This demonstrates the potential for increased surface runoff and erosion from areas not adequately protected with

J.L. Gardner, 1971, personal communication, Las Cruces, New Mexico.
Table 2. Percentage change between initial (dry) and antecedent soil water (wet) tests for the different treatments.

\begin{tabular}{lcc}
\hline \hline Treatments & $\begin{array}{c}\text { Infiltration } \\
(\mathrm{cm} / \mathrm{hr})\end{array}$ & $\begin{array}{c}\text { Percentage } \\
\text { change }\end{array}$ \\
\hline Bare soil (dry) & 4.68 & -70 \\
Bare soil (wet) & 1.39 & \\
Creosotebush (dry) & 9.41 & \\
Creosotebush (wet) & 6.72 & -29 \\
Creosotebush (wet) & 6.72 & \\
Rootplow, 1972 (dry) & 5.51 & -67 \\
Rootplow, 1972 (wet) & 1.80 & \\
Rootplow, 1976 (dry) & 2.25 & \\
Rootplow, 1976 (wet) & 3.39 & +51 \\
\hline
\end{tabular}

a vegetation cover.

Even though the surface of the rootplowed plots was rougher than that of the untreated areas, this roughness was not adequate to minimize surface runoff when compared to vegetated plots.

These data indicate a hydrologic advantage for creosotebush covered arid rangeland because of the increased infiltration and reduced runoff for up to 4 years following the rootplow and seed treatment. The rootplow and seeding treatment does offer protection, especially after some time, as shown by the better infiltration on the RP 2 treatment as compared with the RP6 treatment.

\section{Literature Cited}

Branson, F.A. R.F. Miller, and I.S. McQueen. 1966. Contour furrowing, pitting, and ripping on rangelands of the western United States. J Range Manage. 19: 182-190.

Brown, A.L., and A.C. Everson. 1952. Longevity of ripped furrows in southern Arizona desert grassland, J. Range Manage. 5: 415-419.

Dixon, R.E. 1966. Water infiltration responses to soil management practices. Ph.D. Thesis, Univ. Wisconsin. Univ. Microfilm, Diss. Abst. XXVII: 4, Ann Arbor, Mich. 174 p.

Dortignac, E.J., and W.C. Hickey. 1963. Surface runoff and erosion as affected by soil ripping. Proc. of the Federal Inter-Agency Sedimentation Conf., U.S. Dep. Agr. Misc. Pub. 1970: 156-165.

Duley, F.L., and L.L. Kelley. 1939. Effect of soil type, slope, and surface conditions on intake of water. Nebraska Agr. Exp. Sta. Bull. 112.

Horton, R.E. 1940. An approach toward a physical interpretation of infiltration capacity. Soil Sci. Soc. Amer. Proc. 5: 399-417.

Kincaid, D.R., J.L. Gardner, and H.A. Schreiber. 1964. Soil and vegetation parameters affecting infiltration under semiarid conditions. Inst. Ass. Sci. Hydrol. Bull. 65: 440-453.

Kincaid, D.R., and G. Williams. 1966. Rainfall effects on soil surface characteristics following range improvement treatments. J. Range Manage. 19: 346-351.

Musgrave, G.W. 1955. How much of the rain enters the soil? In: Water, 155-159, U.S. Dep. Agr. Yearbk.

Rauzi, F., and C.L. Fly. 1968. Water intake on midcontinental rangelands as influenced by soil and plant cover. U.S. Dep. Agr. Tech. Bull. 1390.

Rowe, P.B., and L.F. Reimann. 1961. Water use by brush, grass, and grassforb vegetation, J. Forest. 59: 175-181.

Schreiber, H.A., and D.R. Kincaid. 1967. Regression models for predicting on-site runoff from short-duration convection storms. Water Resourc. Res. 3(2): 389-395.

Soil Conservation Service. 1972. National Engineering Handbook, Section 4, Hydrology (revised ed.) Soil Conservation Service, U.S. Dep. Agr., Washington, D.C.

Soil Conservation Service, White Sands Missile Range, New Mexico. 1976. Soil Conservation Service, U.S. Dep. Agr., State Office, Albuquerque, New Mexico.

Tromble, J.M. 1976. Semiarid rangeland treatment and surface runoff. J. Range Manage. 29: 251-255. 